\title{
Equine herpesvirus type 1 infection induces procoagulant activity in equine monocytes
}

Wee Ming Yeo ${ }^{1}$, Nikolaus Osterrieder ${ }^{2}$ and Tracy Stokol ${ }^{1^{*}}$

\begin{abstract}
The alphaherpesvirus, equine herpesvirus type 1 (EHV-1), is a highly prevalent cause of equine infectious abortion and encephalomyelopathy. These syndromes have been attributed to ischemic necrosis from thrombosis in placental and neural vessels, although the mechanisms underlying thrombosis are unknown. After inhalation, EHV-1 establishes a peripheral blood mononuclear cell-associated viremia, with monocytes being a target of infection. Monocytes are also the main source of tissue factor (TF) in diseased states. Since TF is the primary activator of coagulation, increased monocyte TF expression could be involved in EHV-1-associated thrombosis. We hypothesized that EHV-1 infection would induce TF-dependent procoagulant activity in equine monocytes. Monocyte-enriched fractions of blood were infected with abortigenic (RacL11, NY03) and neuropathogenic (Ab4) EHV-1 strains. All strains induced procoagulant activity, to variable degrees, within 1 to $4 \mathrm{~h}$, with maximal activity at $24 \mathrm{~h}$, after infection. Virus-induced procoagulant activity was similar to that seen with lipopolysaccharide, a known stimulant of TF-mediated procoagulant responses. Virus-induced procoagulant activity was factor Vlla-dependent and temporally associated with TF gene transcription, implicating TF as the main driver of the activity. Procoagulant activity was mildly decreased (30-40\%) when virus was inactivated by ultraviolet light or when infected cells were treated with aphidicolin, a virus DNA polymerase inhibitor, suggesting early events of virus infection (attachment, entry or intracellular trafficking) are the primary stimulus of procoagulant activity. Our results indicate that EHV-1 rapidly stimulates procoagulant activity in equine monocytes in vitro. The EHV-1-induced procoagulant activity in monocytes may contribute to clinical thrombosis in horses with EHV-1 infection.
\end{abstract}

\section{Introduction}

Equine herpesvirus type 1 (EHV-1) is a member of the genus Varicellovirus within the Alphaherpesvirinae subfamily and has a double stranded DNA genome. It is highly prevalent and pathogenic in horses, causing large-scale outbreaks of respiratory disease, abortion storms and encephalomyelopathy [1]. Horses are exposed to EHV-1 through aerosolization [1-2]. After primary replication in the respiratory epithelium, the virus disseminates systemically through a peripheral blood mononuclear cell (PBMC)-associated viremia [3-7]. The EHV-1-associated disease syndromes of abortion and encephalomyelopathy have been attributed to ischemic injury from thrombosis in vessels of the placenta and the central nervous system, mostly in the spinal cord, respectively [8-10].

\footnotetext{
* Correspondence: ts23@cornell.edu

${ }^{1}$ Department of Population Medicine and Diagnostic Sciences, College of Veterinary Medicine, Cornell University, Ithaca, NY, USA

Full list of author information is available at the end of the article
}

Infectious agents, including bacteria and viruses, can activate the hemostatic system, resulting in a hypercoagulable state that can manifest as thrombosis or disseminated intravascular coagulation [11-13]. Experimental models have revealed that upregulation of tissue factor (TF) expression on monocytes is the main trigger for hypercoagulability in bacterial sepsis $[14,15]$, however the mechanisms underlying hemostasis activation with virus infection are less well understood. In vitro studies have shown that viruses can upregulate TF in infected endothelial cells [16-18]. However, monocytes are now considered the main source of TF in inflammatory states, including that due to bacterial sepsis $[14,19]$. Far less is known of the role of monocytes in virus-induced hypercoagulability. Four bovine respiratory viruses upregulated TF in alveolar macrophages in vitro [20] while cytomegalovirus (a betaherpesvirus) and influenza virus induced TF-dependent procoagulant activity in human monocytes in vitro [21]. In vivo studies have 
associated TF expression on monocytes with abnormalities in hemostasis in several virus infections [22-24].

The mechanisms of thrombosis in EHV-1 infection have not been established, although endothelial injury certainly may be involved $[3,9,10]$. However, blood monocytes are susceptible to EHV-1 infection in vitro and in vivo [2,5,25-27] and may serve as the primary virus transporters to endothelial cells at sites distant from the respiratory tract $[2,28,29]$. Since monocytes are also the source of induced TF expression in disease states, we hypothesized that EHV-1 infection would induce procoagulant activity in equine peripheral blood monocytes in a TF-dependent manner. Monocyte-enriched fractions from equine peripheral blood were infected with abortigenic (RacL11, NY03) and neuropathogenic (Ab4) strains of EHV-1. At various times after infection with live or inactivated virus, monocyte procoagulant activity was measured with a two-stage amidolytic activity assay, based on the generation of activated factor X (FXa). TF mRNA was also quantified at different times after infection and flow cytometric analysis was performed to verify infection of monocytes by EHV-1 and determine if EHV-1 induced cell death in infected monocytes.

\section{Materials and methods}

\section{Virus amplification, concentration and titration}

The following EHV-1 strains were used: RacL11 $1_{\mathrm{D} 752}$, $\mathrm{Ab}_{\mathrm{D} 752}, \mathrm{NY03}_{\mathrm{N} 752}, \mathrm{Ab} 4_{\mathrm{D} 752}$ expressing green fluorescent protein $\left(\mathrm{Ab} 4_{\mathrm{D} 752^{-}} \mathrm{GFP}\right), \mathrm{RacL}_{1} 1_{\mathrm{N} 752^{-}} \mathrm{GFP}$ and $\mathrm{Ab} 4_{\mathrm{N} 752^{-}}$ GFP. The RacL11 strain was isolated from an aborted fetus in the 1950s [30], whereas Ab4 was isolated from a quadriplegic mare that had previously aborted during an EHV-1 outbreak in 1980 [9]. NY03 is an isolate from an aborted fetus in the state of New York in 2003 [31]. Wild-type RacL11 and Ab4 strains contain a single $G$ to A polymorphism in the catalytic subunit of the EHV-1 DNA polymerase at position 2554, which results in a single amino acid substitution of aspartic acid (D) for asparagine $(\mathrm{N})$ at position $752\left(\mathrm{D}_{752}\right)$ that was shown to be associated with neurological disease [25,27,32,33]. The NY03 strain has a $G$ nucleotide at this position $\left(\mathrm{N}_{752}\right)$. The mutant viruses, RacL11 $1_{\mathrm{N} 752}-\mathrm{GFP}$ and

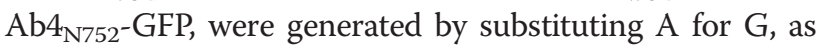
previously described [25]. GFP-expressing strains were produced by substituting the GFP gene for the virus gene 71 , which encodes for the nonessential glycoprotein gp2, as previously described [34]. A clinical equine herpesvirus type 4 (EHV-4) field isolate was kindly provided by $\mathrm{Dr}$ Dubovi (Cornell University). All EHV-1 strains were propagated in rabbit kidney cells (RK13), which were cultured in Dulbecco's Modification of Earl's Medium (Mediatech, Inc.) supplemented with L-glutamine, glucose, sodium pyruvate and $10 \%$ fetal bovine serum (Atlanta Biologicals, Inc.) and grown in $75 \mathrm{~cm}^{2}$ flasks (Corning
Inc.) at $37^{\circ} \mathrm{C}$ under $5 \%$ carbon dioxide. One-day-old confluent monolayers of RK13 cells were infected with the respective virus strains at a multiplicity of infection (MOI) of 0.1 until a cytopathic effect of approximately $90 \%$ was achieved. The flasks were then subjected to two freeze-thaw cycles. The respective culture media were centrifuged at $1800 \times g$ for $15 \mathrm{~min}$ at $4^{\circ} \mathrm{C}$, aliquoted, and subjected to ultracentrifugation at $175000 \times g$ for $1 \mathrm{~h}$ at $4^{\circ} \mathrm{C}$. The supernatant was removed (and stored for later use as a negative control) and the pellet was reconstituted with $1 \mathrm{~mL}$ sterile phosphate-buffered saline (PBS, pH 7.4) and stored at $-20^{\circ} \mathrm{C}$. The virus titers of the respective concentrates were determined using a standard plaque assay.

\section{Virus infection of monocyte-enriched and monocyte-} depleted fractions of peripheral blood mononuclear cells Peripheral blood was collected with minimal restraint on multiple different occasions from the jugular vein of 14 non-pregnant Thoroughbred mares ranging in age from 3 to 20 years, using a blood collection set (40 inch, MWI Veterinary Supply). Blood was collected directly into a 250 $\mathrm{mL}$ evacuated container (Baxter Healthcare Corporation), containing heparin (10 units/mL, Sigma-Aldrich). All animal procedures were approved by the Cornell University Institutional Animal Care and Use Committee and were in accordance with the guidelines established by the National Institutes of Health. Leukocyte-rich plasma was obtained by gravity sedimentation of erythrocytes for 20 min at room temperature. The plasma was then centrifuged at $288 \times g$ for $10 \mathrm{~min}$ at $20^{\circ} \mathrm{C}$. The cell pellet was resuspended with $\mathrm{PBS}(\mathrm{pH} 7.2)$, then layered onto Histopaque 1.077 (GE Healthcare) at a ratio of 2:1 cell suspension to Histopaque and centrifuged at $468 \times g$ for $15 \mathrm{~min}$ at $20^{\circ} \mathrm{C}$. The PMBC layer was removed, washed twice in PBS, and then was resuspended in MACS buffer (MACS, Miltenyi Biotec). The cell suspension was incubated with a murine monoclonal anti-equine CD14 antibody (clone 105, $20 \mu \mathrm{g} / \mathrm{mL}$ ) [35] for $15 \mathrm{~min}$ at $4^{\circ} \mathrm{C}$. Antibody-bound cells were positively selected by incubation with a secondary rat anti-mouse antibody conjugated to metal beads (Miltenyl Biotec, 1:100) for $15 \mathrm{~min}$ at $4^{\circ} \mathrm{C}$ followed by passage through a magnetic column as recommended by the manufacturer. The sorted (monocyte-enriched) and flow through (monocyte-depleted) fractions were washed in PBS and resuspended in RPMI medium containing 10\% autologous plasma that had been rendered free of cell-derived microparticles by two steps of high-speed centrifugation at $21130 \times g$ for $30 \mathrm{~min}$ at $4^{\circ} \mathrm{C}$. The percentage of monocytes in each fraction was determined by performing differential cell counts on 200 leukocytes in Wright's-stained cytospin smears prepared from each fraction immediately after sorting. The cells were seeded at a density of $5 \times 10^{5}$ cells/well in 96-well 
tissue culture plates and immediately infected with the various EHV-1 strains at an MOI of 1 or 5 for $1 \mathrm{~h}$ at $37^{\circ} \mathrm{C}$. The infected cells were then washed twice with warmed PBS to remove non-infectious virus particles and fresh media was added. Vehicle (PBS) and lipopolysaccharide (LPS, $10 \mathrm{ng} / \mathrm{mL}$, Sigma-Aldrich) served as negative and positive [36] controls, respectively. Infected and control (uninfected) cells from the same horse were incubated simultaneously for various times $(1,2,4$ or $24 \mathrm{~h})$ in a humidified chamber at $37^{\circ} \mathrm{C}$ with $5 \%$ carbon dioxide. In some experiments, viruses were inactivated by exposure to ultraviolet (UV) light for $20 \mathrm{~min}$ before infection or infected cells were treated with the virus DNA polymerase inhibitor, aphidicolin (10 $\mu \mathrm{M}$, Sigma-Aldrich), which was added after $1 \mathrm{~h}$ of virus adsorption.

\section{Measurement of procoagulant activity on monocyte surfaces}

Infected and control cells $\left(5 \times 10^{5}\right)$ were washed twice with HEPES buffer (10 mM HEPES, $137 \mathrm{mM}$ sodium chloride, $5 \mathrm{mM}$ calcium chloride, $4 \mathrm{mM}$ potassium chloride, $10 \mathrm{mM}$ glucose, $0.5 \%$ bovine serum albumin, $\mathrm{pH}$ 7.4), then procoagulant activity was measured using a standard two-step amidolytic assay based on FXa generation. In brief, recombinant human activated factor VII (FVIIa, final concentration, $1 \mathrm{nM}$, Hematologic Technologies) and factor X (FX, final concentration, 75 $\mathrm{nM}$, Hematologic Technologies) diluted in HEPES buffer were added to the cells for $15 \mathrm{~min}$ at $37^{\circ} \mathrm{C}$. Chromogenic substrate (Spectrozyme-FXa, final concentration, 167 $\mu \mathrm{M}$, American Diagnostica) was then added and the ensuing color change was measured after 10 minutes at an optical density of $405 \mathrm{~nm}$ at $37^{\circ} \mathrm{C}$ with a plate spectrophotometer (Synergy 2, Biotek, Winooski, VT, USA). Optical density results were converted to the amount of FXa generated (nM) based on a standard curve created from serial dilutions of human recombinant FXa (American Diagnostica) that were incubated with the substrate for $10 \mathrm{~min}$. The standard curve was linear between FXa concentrations of 4.69 and $0.29 \mathrm{nM}$, the latter yielding optical densities more than twice baseline values (infected or control cells with no exogenous FX or chromogenic substrate). For data analysis, values above and below the linearity of the standard curve were standardized to 4.69 and $0 \mathrm{nM}$ FXa, respectively. Human recombinant TF (Innovin, Dade-Behring) with added reagents was included as a positive assay control.

\section{Quantitative real-time PCR for TF mRNA}

Total RNA was isolated with the RNeasy mini kit (Qiagen), using RNase-Free DNase, according to the manufacturer's protocol. Complementary DNA (cDNA) was synthesized using Superscript III first strand reverse transcriptase kit (Life Technologies) according to the manufacturer's protocol. Resulting cDNA concentrations were measured at $260 \mathrm{~nm}$ with a nanodrop spectrophotometer (NanoVue, GE Healthcare). Gene-specific and housekeeping gene (equine $\beta 2$-microglobulin) primers were designed using the NCBI primer blast program and the final sequences were verified against the available mammalian genome database (NCBI/BLAST) to avoid non-specific homology (Table 1). Quantitative PCR was performed on $200 \mathrm{ng}$ cDNA samples using PowerSybr green in a MicroAmp Fast Optical 96-well reaction plate (Applied Biosystems) according to the manufacturer's protocol. Samples were run in duplicate or triplicate on an ABI StepOnePlus Real Time PCR system in standard mode, with $10 \mathrm{~min}$ of denaturation at $95^{\circ} \mathrm{C}$, followed by 40 cycles of $15 \mathrm{~s}$ at $95^{\circ} \mathrm{C}$ and $60 \mathrm{~s}$ at $60^{\circ} \mathrm{C}$ and $60 \mathrm{~s}$ at $72^{\circ} \mathrm{C}$. Melting curve analysis was used to confirm the presence of a single PCR product. The data were analyzed with the $\Delta \Delta C T$ method [37], with results being normalized to the housekeeping gene and expressed as the $\log _{2}$ fold difference in target quantity between the test sample and vehicle-treated control (set to 0 ).

Flow cytometric analysis of virus infectivity of monocytes Monocyte-enriched and -depleted cultures were infected with RacL11 $1_{\mathrm{N} 752}$-GFP and Ab4 $4_{\mathrm{D} 752}$-GFP at an MOI of 1 for $24 \mathrm{~h}$, with vehicle (PBS) and non-GFP-expressing virus as controls. The samples were then labeled with an Alexa647 (A647)-conjugated murine anti-equine CD14 antibody (clone 105) or an A647-conjugated isotype control for $15 \mathrm{~min}$ at $4^{\circ} \mathrm{C}$ and washed three times with PBS. Then 15000 cells/sample were analyzed on a FACSCaliburTM flow cytometer (Becton Dickinson) using the following settings: forward scatter (FSC): E00 voltage, 1.14 amp gain, linear mode, threshold 180; side scatter (SSC): 434 voltage, $1.00 \mathrm{amp}$ gain, linear mode; and fluorescence on log mode. The percentage of cells that were positive for A647-CD14 or GFP was measured on quadrant dotplots.

\section{Flow cytometric assessment of cell death}

To determine if EHV-1 induced cell death, we infected cells for 4 or $24 \mathrm{~h}$ with all EHV-1 strains at an MOI of 1 and 5 and then measured changes in mitochondrial transmembrane potential $(\Delta \Psi \mathrm{m})$ by staining with a fluorescent cationic dye and monitoring changes in fluorescence with flow cytometry, according to the manufacturer's protocol (DePsipherTM kit, Trevigen Inc.). For analysis, monocytes were gated based on their FSC and SSC characteristics. In healthy cells with a high negative $\Delta \Psi \mathrm{m}$, the lipophilic cationic dye accumulates in the mitochondrial matrix as a multimer and fluoresces bright red (FL2 channel). Red fluorescence is lost when the cells have altered mitochondrial membrane permeability, an early marker of apoptosis [38]. Since changes in $\Delta \Psi \mathrm{m}$ 
Table 1 Primers used for measurement of equine TF mRNA by quantitative real-time PCR

\begin{tabular}{|c|c|c|c|}
\hline Gene & Length (bp) & Amplicon size & Sequence $\left(5^{\prime}-3^{\prime}\right)$ \\
\hline Equus caballus TF forward & 23 & 243 & 5' - GTGGCTAGAGCCGCAGGGACTAG \\
\hline Equus caballus TF reverse & 21 & 243 & 5' - AGGAAGAGACCCGCGCCATGT \\
\hline Equus caballus $\beta 2$-microglobulin forward & 22 & 209 & 5' - TGTCTCTGGGTTCCATCCGCCT \\
\hline Equus caballus $\beta 2$-microglobulin reverse & 25 & 209 & 5' - CGGACCCACTTAACTATCAGGGGGT \\
\hline
\end{tabular}

are potentially reversible [39], we also performed a live-dead assay by staining for Annexin $\mathrm{V}$ and measuring propidium iodide uptake $\left(\mathrm{TACS}^{\circledR}\right.$ Annexin V-FITC kit, Trevigen Inc), according to the manufacturer's protocol. This was done on monocyte-enriched fractions infected with RacL11 at an MOI of 1 or 5 for 4 or $24 \mathrm{~h}$. Cells treated with LPS $(10 \mathrm{ng} / \mathrm{mL}$ or $10 \mu \mathrm{g} / \mathrm{mL})$ and sodium azide (25 mM, Sigma-Aldrich) served as positive treatment and cell death controls, respectively, whereas vehicle- (PBS) treated cells were used as a negative control for all cell death experiments.

\section{Statistical analysis}

Data were parametric and results are expressed as mean $\pm \mathrm{SD}$ values. Comparison between multiple means was performed with a 1-way ANOVA followed by a Tukey's Multiple Comparison Test. Comparison of two means was performed with a paired t-test (Prism 5.0 for Mac OS, version 5.0c, GraphPad Software Inc). Significance was set at $p<0.05$.

\section{Results}

\section{EHV-1 infection of monocytes and induction of} procoagulant activity

To verify that monocytes were infected with EHV-1 in vitro, flow cytometric analysis with the GFP-expressing variants RacL11 $1_{\mathrm{N} 752}$ and $\mathrm{Ab} 4_{\mathrm{D} 752}$ was done. A monocyte purity of $81 \pm 7 \%$ (range $65-88 \%, n=10$ ) was obtained in the monocyte-enriched fraction with the anti-equine CD14-based immunopurification technique, as assessed by differential leukocyte counts on cytospin preparations of the fraction. Flow cytometric analysis was performed 24 $\mathrm{h}$ after infection of monocyte-enriched and -depleted fractions to allow time for virus infection and replication. Monocytes were the predominant cell type infected with the RacL11 strain $(43.9 \pm 2.2 \%)$ in both fractions (Figure 1$)$. Similar observations were made when the Ab4 strain was used (data not shown), but infection rates were slightly lower with this strain $(38.4 \pm 2.8 \%)$.

Monocyte-enriched and -depleted fractions were then infected with the RacL11 strain of EHV-1 at an MOI of 5 for $4 \mathrm{~h}$, using LPS $(10 \mathrm{ng} / \mathrm{mL})$ as a positive control. This time point was initially chosen because it is close to the peak procoagulant activity previously reported for LPS-stimulated equine monocytes [36]. Both RacL11 infection and LPS treatment caused a significant increase in procoagulant activity in the monocyteenriched fraction compared to the monocyte-depleted fraction and vehicle-treated controls. The increase in procoagulant activity was significantly higher after LPS stimulation than after RacL11 infection (Table 2). The procoagulant activity of both negative controls and RacL11-infected or LPS-treated monocyte-depleted fractions were below the assay detection limit. Two other EHV-1 strains, Ab4 and NY03, also induced procoagulant activity in equine monocyte-enriched fractions after $4 \mathrm{~h}$ of infection, although the response was highest with the RacL11 strain (Figure 2A). Because inhibitory antibodies against equine $\mathrm{TF}$ are unavailable, controls lacking exogenous FVIIa were used as a surrogate marker of TF involvement in the induced procoagulant activity. The increase in procoagulant activity after infection with all EHV-1 strains (MOI of 1 or 5) and LPS stimulation was abolished in the absence of exogenous FVIIa (Table 3, only RacL11 is shown at an MOI of 1) supporting TF-triggered, FVIIa-dependent generation of FXa. The induced procoagulant activity was not due to LPS contamination of purified virus because virus-free supernatants obtained after ultracentrifugation did not stimulate any procoagulant activity in the monocyteenriched fractions (data not shown). Other herpesviruses can acquire TF from the membranes of the host cells they are propagated in [40]. All three purified virus alone (tested at concentrations similar to an MOI of 5) expressed small amounts of TF that were usually below the limit of detection of the assay ( 0.19 to $0.39 \mathrm{nM}$ FXa), but higher than the negative controls (virus preparations with no added FX or substrate). The amount of FXa generated by the virus alone was far lower than that induced by virus infection or LPS stimulation of cells. This data suggests that EHV-1, similar to other herpesviruses, do acquire TF from the propagating rabbit kidney cellular membranes, but the small amount of procoagulant activity on the purified virus is insufficient to account for the observed activity in infected equine monocytes.

Time course of EHV-1 induction of procoagulant activity and TF mRNA expression in equine monocytes

Procoagulant activity was measured in monocyte-enriched fractions at 1, 2, 4 and $24 \mathrm{~h}$ after infection with all 3 virus strains at an MOI of 1 or 5 in different experiments. At an MOI of 1 , procoagulant activity was evident at $4 \mathrm{~h}$ after 


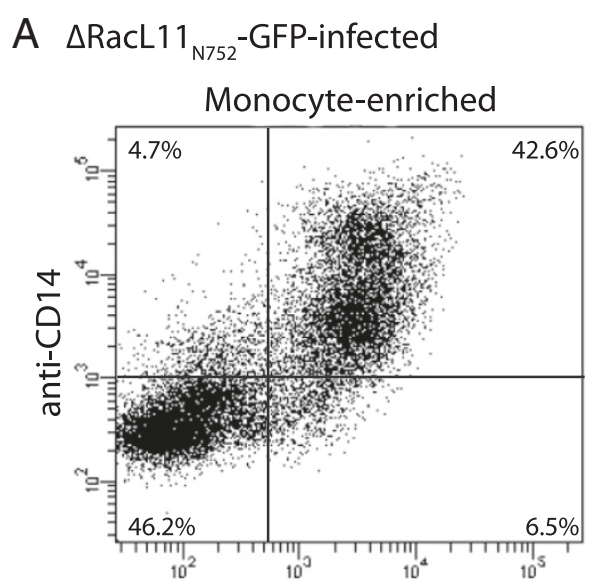

GFP fluorescence units

\section{B Mock-infected}

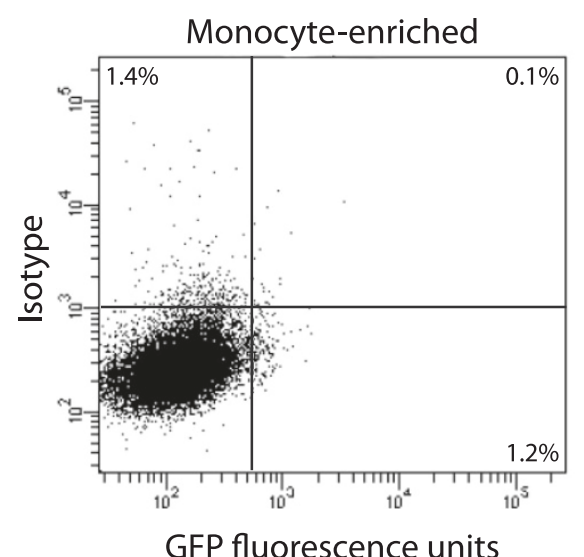

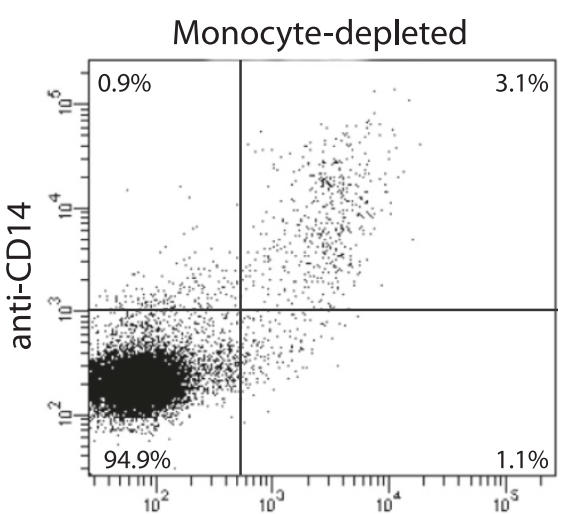

GFP fluorescence units

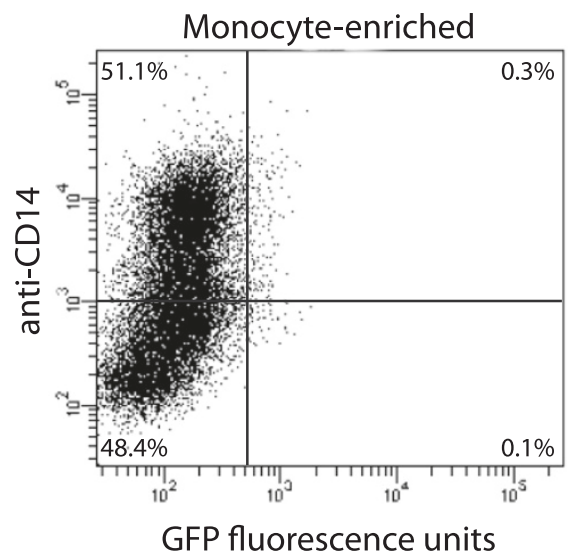

Figure 1 EHV-1 preferentially infects equine monocytes in peripheral blood mononuclear cells. Monocytes were enriched from equine PBMC using an anti-equine CD14 antibody and immunomagnetic beads. Monocyte-enriched (A, left panel) and -depleted (A, right panel) fractions of PBMC $\left(5 \times 10^{5}\right.$ cells) were infected for $24 \mathrm{~h}$ with RacL $11_{\mathrm{N} 752}$-GFP (MOI of 1), then labeled with an A647-conjugated anti-CD14 antibody, after which 15000 cells were analyzed for EHV-1 infection (GFP-positivity) by flow cytometry. Mock-infected monocyte-enriched fractions labeled with an A647-isotype antibody (B, left panel) or A647-conjugated anti-CD14 antibody (B, right panel) served as negative controls, with the isotype control being used to define the quadrants. Numbers in each quadrant represent percentage of total events. The majority of GFP-positive cells (upper and lower right quadrants) in EHV-1-infected monocyte-enriched and -depleted fractions are CD14-positive monocytes (upper right quadrant).

EHV-1 infection. At this MOI, procoagulant activity at earlier time points of EHV-1 infection and in all vehicle treated controls was below the assay detection limit (Figure 2A, left panel). In contrast, at an MOI of 5, procoagulant activity was observed as soon as $1 \mathrm{~h}$ after virus infection and was significantly higher with all three virus strains compared to vehicle negative and LPS positive controls at this time point (Figure 2A, right panel). Furthermore, the induced procoagulant activity was higher at an MOI of 5 compared to an MOI of 1 at all time points with all virus strains (Figure 2A, left versus right panel). Procoagulant activity was maximal $24 \mathrm{~h}$ after infection at both MOI or LPS stimulation. RacL11 consistently induced the highest procoagulant activity of all virus strains (Figure 2A). Basal procoagulant activity and the degree of change in procoagulant activity varied between individual horses and experiments. Similar variability in basal and stimulated procoagulant activity is a recognized phenomenon with human monocytes [41].

To determine if the induction of procoagulant activity due to EHV-1 was associated with TF gene transcription, quantitative real-time PCR was performed at 1,4 and 24 $\mathrm{h}$ after EHV-1 infection at an MOI of 1 and 5 or LPS stimulation. An increase in TF mRNA expression occurred within $1 \mathrm{~h}$ of infection with RacL11 at both MOI, which paralleled the TF mRNA response to LPS (Figure 2B). Similar to changes in procoagulant activity, there was a greater relative increase in TF mRNA 
Table 2 EHV-1 induces procoagulant activity primarily in the monocyte-enriched fraction of equine peripheral blood mononuclear cells

\begin{tabular}{llll}
\hline Treatment & Vehicle & RacL11 & LPS \\
\hline Monocyte-enriched & 0 & $2.36 \pm 0.05^{* *}$ & $2.78 \pm 0.07^{* *}$ \\
Monocyte-depleted & 0 & 0 & 0 \\
\hline
\end{tabular}

Monocytes were purified using a murine anti-equine CD14 antibody and procoagulant activity was measured in monocyte-enriched and -depleted PBMC fractions with a two-stage amidolytic assay $4 \mathrm{~h}$ after infection with RacL11 (MOI of 5), using LPS (10 ng/mL) positive and vehicle (PBS) negative controls. Data represents the mean \pm SD of FXa generation $(\mathrm{nM})$ from 3 horses. * $p<0.05$ comparing all treatments for monocyte-enriched cells. ** $p<0.05$ versus the monocyte-depleted fraction.

expression at the higher MOI of 5 at all measured time points (Figure 2B, left versus right panel). The upregulated mRNA expression peaked at $4 \mathrm{~h}$ (preceding the peak procoagulant activity), then began to return to baseline levels at $24 \mathrm{~h}$ after infection or stimulation
(Figure 2B). Similar results were observed with the Ab4 and NY03 EHV-1 strains at an MOI of 5 (data not shown).

\section{Effect of the $D_{752}$ polymorphism in the virus DNA}

\section{polymerase on EHV-1-induced procoagulant activity}

The RacL11 -and Ab4 EHV-1 strains both contain the $\mathrm{D}_{752}$ polymorphism, which has been associated with neurovirulence $[25,27,32,33]$, whereas the NY03 strain has the $\mathrm{N}_{752}$ polymorphism in the virus DNA polymerase. The observation that all 3 EHV-1 strains induced procoagulant activity in equine monocytes, albeit to different degrees (Figure 2), argues against a major role for this known pathogenic polymorphism in the induction of procoagulant activity. To more directly determine the effect of this polymorphism on procoagulant activity, monocyte-enriched fractions were infected with wild type EHV-1 RacL11 $1_{\mathrm{D} 752}$ and $\mathrm{Ab} 4_{\mathrm{D} 752}$ and

A Time course of procoagulant activity
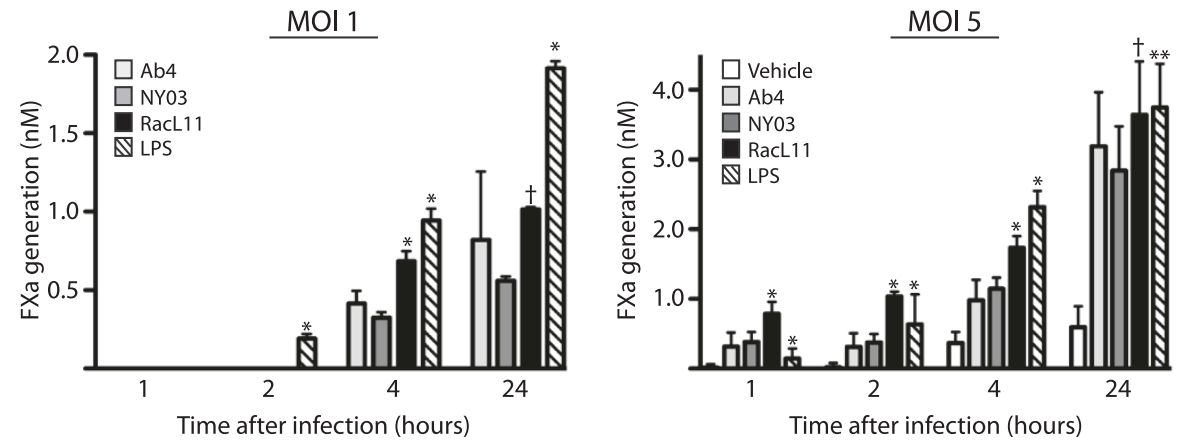

B mRNA expression
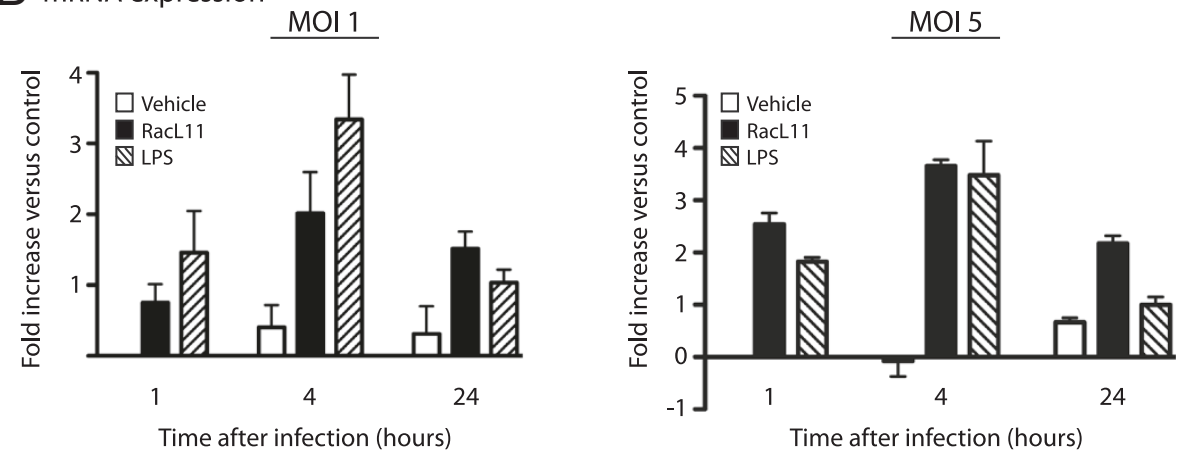

Figure 2 Time course of procoagulant activity and mRNA expression after EHV-1 infection of equine monocytes. A: Monocyte-enriched fractions of equine PBMC $\left(5 \times 10^{5}\right.$ cells) were infected with the RacL11, Ab4 or NY03 strains of EHV-1 at an MOI of 1 (left panel, $\left.n=4\right)$ or 5 (right panel, $n=10)$ or treated with LPS (10 ng/mL) positive or vehicle (PBS) negative controls. Procoagulant activity was measured at $1,2,4$ and $24 \mathrm{~h}$ after infection. FXa generation was below the limit of detection at all time points for the vehicle control and at 1 and $2 \mathrm{~h}$ after infection for all viruses at an $\mathrm{MOI}$ of 1 and are subsequently not shown in the left panel. The mean procoagulant activity of cells infected with all viruses or treated with LPS is significantly different than the vehicle control $(p<0.05)$ at all time points, with the following exceptions: 1 or $2 \mathrm{~h}$ after infection with all virus strains at an $\mathrm{MOI}$ of 1 (left panel) and $1 \mathrm{~h}$ after treatment with LPS (both panels). Note, results depicted in the two panels are derived from different horses and experiments. ${ }^{*} p<0.05$ versus other virus strains (for RacL 11) or all virus strains (for LPS) at the same time point. ** $p<0.05$ versus Ab4 or NY03 only. $+p<0.05$ versus NY03 only. B: Time course of quantitative real-time PCR analysis for TF mRNA in monocyte-enriched PBMC fractions infected with RacL11 at an MOl of 1 (left panel) or 5 (right panel) or treated with LPS (10 ng/mL) and vehicle (PBS) controls. The data is expressed as the mean \pm SD $\log _{2}$ fold increase in TF mRNA expression relative to the vehicle-treated control at $1 \mathrm{~h}$ (standardized to 0 ) after normalization to the housekeeping gene, $\beta 2$-microglobulin $(n=3-6)$. 
Table 3 EHV-1- and LPS-induced procoagulant activity is FVIla-dependent

\begin{tabular}{llll}
\hline Treatment & Vehicle & RacL11 & LPS \\
\hline FVlla & 0 & $1.97 \pm 0.27^{*}$ & $2.89 \pm 0.37^{*}$ \\
No FVlla & 0 & 0 & 0 \\
\hline
\end{tabular}

Procoagulant activity (mean \pm SD FXa generation in $\mathrm{nM}$ ) was measured with and without exogenous FVIla in monocyte-enriched PBMC fractions $4 \mathrm{~h}$ after infection with RacL11 (MOI of 1) or treatment with LPS $(10 \mathrm{ng} / \mathrm{mL})$ or vehicle (PBS) $(n=3)$.

* $p<0.05$ versus no FVIla.

isogenic mutants expressing $\mathrm{N}_{752} \quad\left(\right.$ RacL11 $1_{\mathrm{N} 752}$ and $\left.\mathrm{Ab}_{\mathrm{N} 752}\right)$. Both parental and mutant viruses induced procoagulant activity in monocytes, although the degree of induction was significantly lower with the $\mathrm{N}_{752}$ mutant of RacL11 only (Table 4).

\section{Effect of virus inactivation and EHV-4 infection on monocyte procoagulant activity}

To determine if procoagulant activity was induced by early or immediate early (pre-replication) phases of virus infection (attachment, entry or intracellular trafficking) in monocytes, RacL11 was inactivated by exposure to UV light; UV-exposed virus can presumably attach, enter and traffic to the nucleus of cells but is incapable of replication, which was confirmed through virus plaque assays (data not shown). Procoagulant activity was significantly decreased by $29 \pm 5 \%$ at $4 \mathrm{~h}$ of infection when UV-inactivated RacL11 was used at an MOI of 5 (Figure 3A). Similarly, mild decreases in procoagulant activity were observed when monocytes were infected with UV-inactivated Ab4 (31 $\pm 1 \%$ decrease) and NY03 (35 $\pm 1 \%$ decrease). The data suggested that procoagulant activity is mainly induced by events in the early phases of virus infection, but that synthesis of late virus proteins with virus replication contributes to and maximizes the activity. To test this hypothesis, we treated monocytes with the virus DNA polymerase inhibitor, aphidicolin $(10 \mu \mathrm{M})$ [42], during RacL11 infection. Treatment with aphidicolin decreased the procoagulant activity induced by RacL11

Table 4 Effect of the $D_{752}$ polymorphism in the virus DNA polymerase on EHV-1-induced procoagulant activity

\begin{tabular}{ll}
\hline Infection & FXa generation (nM) \\
\hline None (vehicle) & 0 \\
RaCL11 $_{\text {D752 }}$ & $2.24 \pm 0.18^{*}$ \\
RaCL11 $_{\text {N752 }}$ & $1.71 \pm 0.02$ \\
Ab4 & $1.85 \pm 0.10$ \\
Ab452 & $1.78 \pm 0.08$ \\
\hline
\end{tabular}

Monocyte-enriched PBMC fractions were infected with wild type RacL $11_{\mathrm{D} 752}$ and $A b 4_{\mathrm{D} 752}$ strains and engineered mutant strains $\left(\operatorname{RacL}_{1} 1_{\mathrm{N} 752}, \mathrm{Ab} 4_{\mathrm{N} 752}\right)$ at an $\mathrm{MOI}$ of 5 . Procoagulant activity was measured at $4 \mathrm{~h}$ after infection or vehicle (PBS) treatment $(n=4)$.

${ }^{*} p<0.05$ versus mutant strain. All EHV-1 infected cells had significantly higher mean procoagulant activity than vehicle-treated cells. infection to a similar extent as UV inactivation (aphidicolin: $29 \pm 3 \%$; UV inactivation: $35 \pm 5 \%$ ) (Figure 3B). Similar decreases in procoagulant activity were observed in monocytes treated with aphidicolin and infected with Ab4 (25 \pm 16\% decrease) and NY03 (40 \pm $4 \%$ decrease). However, the drug had no effect on basal or LPS-stimulated procoagulant activity (Figure 3B). The data indicated that synthesis of late virus proteins contributes to the observed procoagulant activity in EHV-1-infected monocytes. Since most of the procoagulant activity was induced by pre-replication stages of virus infection, we sought to determine if the procoagulant response was specific to EHV-1 or could be induced by a related herpesvirus. We thus infected monocytes with EHV-4 at an MOI of 5 . We chose EHV-4 because this virus does infect PBMC [43] and mononuclear cells in nasal explants [44] in vitro but is not associated with thrombosis in vivo. We found that EHV-4 did induce procoagulant activity in equine monocytes and that this activity was also dependent on exogenous FVIIa (data not shown), however the response was significantly lower than that observed with EHV-1 and was similar to that seen with UVinactivated EHV-1. Furthermore, unlike EHV-1, the EHV-4-induced procoagulant response was unaffected by UV inactivation (Figure 3A) or aphidicolin treatment (data not shown). We concluded from the data that only the early phases of EHV-4 infection induce procoagulant activity and that EHV-4 replication does not contribute to the phenomenon.

\section{Monocyte cell death after EHV-1 infection}

To determine if the induced monocyte procoagulant activity was due to a secondary effect of virus-induced cell death, as reported for LPS-stimulated human monocytes [45], flow cytometric measurement of mitochondrial transmembrane potential $(\Delta \Psi \mathrm{m})$ was performed in EHV-1-infected monocyte-enriched fractions at 4 and $24 \mathrm{~h}$ after infection. Disruption of $\Delta \Psi \mathrm{m}$ is an early and necessary event of apoptosis [38,39]. $\Delta \Psi \mathrm{m}$ in gated monocytes did not change after $4 \mathrm{~h}$ of infection with all virus strains, regardless of the MOI used (Figure 4A and B left panel, only RacL11 shown), or with LPS stimulation (data not shown), in spite of pronounced increases in procoagulant activity at this time point (Figure $2 \mathrm{~A}$ ). At $24 \mathrm{~h}$ after infection, mild changes in $\Delta \Psi \mathrm{m}$ were seen with all EHV-1 strains at an MOI of 1 (Figure 4A right panel, only RacL11 shown) but changes were minimal after LPS stimulation (Figure $4 \mathrm{C}$, right panel). Marked changes in $\Delta \Psi \mathrm{m}$ were seen $24 \mathrm{~h}$ after infection with all virus strains at an MOI of 5 (Figure $4 \mathrm{~B}$ right panel, only RacL11 shown). Marked changes in $\Delta \Psi \mathrm{m}$ were also seen at both time points with the sodium azide positive control (Figure 4C left panel, only $4 \mathrm{~h}$ shown). 

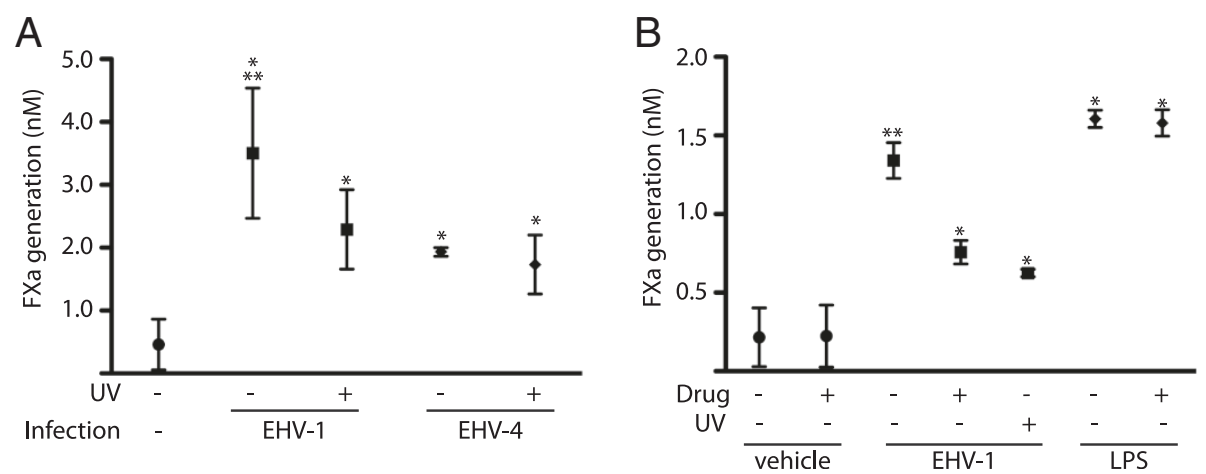

Figure 3 Inactivation of virus with UV light or aphidicolin treatment decreases EHV-1-induced monocyte procoagulant activity. A: UV light inactivation decreases procoagulant activity induced with the RacL11 strain of EHV-1, whereas it has no effect on procoagulant activity induced by EHV-4 $(n=3) .{ }^{*} p<0.05$ versus vehicle negative control. ${ }^{* *} p<0.05$ versus EHV-4-infected cells (active or inactivated). B: Aphidicolin $(10 \mu \mathrm{M})$ decreases the procoagulant activity induced by the RacL11 strain of EHV-1, but has no effect on basal procoagulant activity or that induced by LPS $(10 \mathrm{ng} / \mathrm{mL})(n=3)$. The degree of inhibition of procoagulant activity with UV light inactivation and aphidicolin are similar. Note, results depicted in Figure $3 \mathrm{~A}$ and $\mathrm{B}$ are derived from different horses. ${ }^{*} p<0.05$ versus untreated or drug-treated vehicle (PBS) control. ${ }^{* *} p<0.05$ versus UV light-exposed or aphidicolin-treated virus.

Changes in $\Delta \Psi \mathrm{m}$ are potentially reversible [39], thus we determined the percentage of dead cells (based on Annexin V staining and/or propidium iodide uptake). Monocytes were gated on their characteristic FSC and SSC (R1) after infection with RacL11 at an MOI of 1 or 5 for 4 or $24 \mathrm{~h}$ or treatment with vehicle (PBS), LPS (10 $\mu \mathrm{g} / \mathrm{mL}$ ) or sodium azide (Figure 5 , Table 5 ). We found that a similar percentage of monocytes were reactive with Annexin $\mathrm{V}$ or exhibited propidium iodide uptake after EHV-1 infection at both MOI or after treatment with PBS or LPS at both time points (Figure 5, Table 5, only $24 \mathrm{~h}$ shown). A significantly higher proportion of gated monocytes were dead at 24 versus $4 \mathrm{~h}(19.3 \pm 7.6 \%$ versus $9.5 \pm 5.8 \%, p=0.003$, data of all treatments combined for each time point). Also, the total percentage of events within the monocyte gate (R1) was not significantly different between treatments at either time point. In contrast, there were fewer total events and more dead cells in the monocyte gate after sodium azide treatment at both time points (Table 5, only $24 \mathrm{~h}$ time point shown). We noticed that, after in vitro culture, there was an additional event population with similar SSC but lower FSC compared to monocytes (Figure 5, R2) that was absent in monocyte-enriched fractions evaluated immediately after purification (data not shown). A similar population of cells has been observed in LPS and calcium ionophorestimulated human monocytes and corresponds to dead cells on live-dead staining [46]. We found that this additional population was, indeed, comprised of dead cells, regardless of infection or treatment (Figure 5, Table 5). Furthermore, the percentage of events within this gate was similar with all treatments at both time points, except for sodium azide, which had, on average, double the total events (Table 5). This increase in total events in the "dead cell" or R2 gate with sodium azide corresponded to the reduction of total events in the monocyte or R1 gate, implying the increased total R2 events after sodium azide treatment represented dead monocytes (originally in the R1 gate). We also tested if procoagulant activity was induced in cells treated with sodium azide and found no significant increase in procoagulant activity (data not shown). We concluded from the results that the increase in procoagulant activity in EHV-1-infected monocytes at $24 \mathrm{~h}$ after infection is unlikely due to overt apoptotic cell death.

\section{Discussion}

For the first time, this study shows that EHV-1 infection of equine monocytes induces procoagulant activity that is mediated by increased TF gene expression and availability. The data also suggests that virus-induced procoagulant activity is a two-step process: initial virus binding or uptake induces most of the activity, but virus replication is required for maximal activity. There is also a dose-related response, with higher infectious doses yielding higher procoagulant activity.

The increased monocyte procoagulant activity after virus infection was temporally and quantitatively associated with TF mRNA expression and dependent on addition of exogenous FVIIa. Similar findings were seen with LPS stimulation. This indicates that TF is the main driver of the observed activity and activity is mostly mediated through TF gene transcription with subsequent protein expression on monocyte surfaces, as reported for LPS stimulation [47]. The signaling events by which EHV-1 stimulates TF mRNA production are currently unknown, but the virus could trigger the same pathways that result in TF gene expression after LPS stimulation, including 

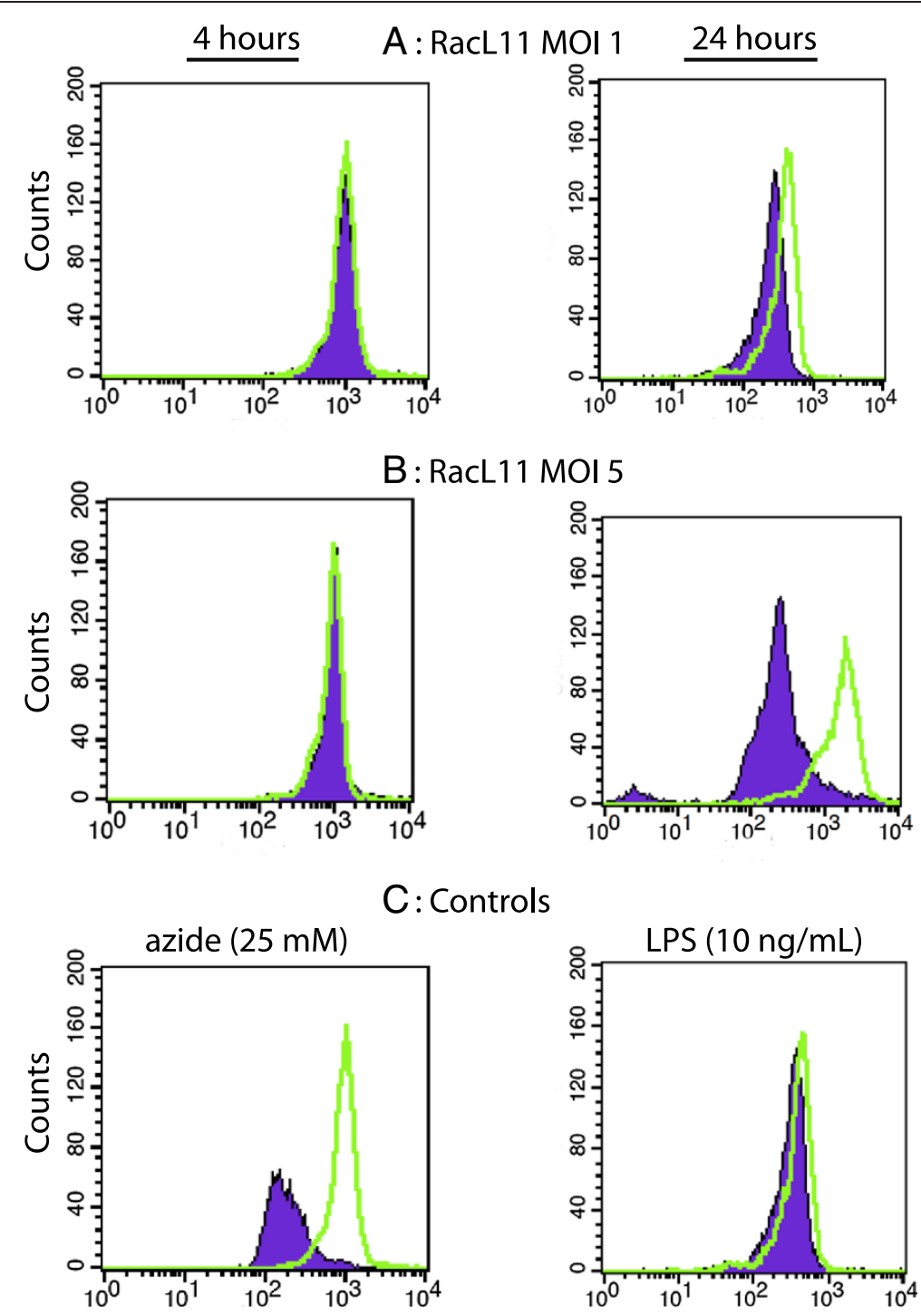

Fluorescence units (FL2)

Figure 4 Changes in mitochondrial membrane potential $\left(\Delta \Psi_{\mathrm{m}}\right)$ after EHV-1 infection. Monocyte-enriched fractions of equine PBMC $\left(5 \times 10^{5}\right.$ cells) were infected for 4 (left panel) or $24 \mathrm{~h}$ (right panel) with the RacL11 strain of EHV-1 at an MOl of 1 (A) or 5 (B). Positive apoptosis and stimulation controls were sodium azide $(25 \mathrm{mM})$ and LPS $(10 \mathrm{ng} / \mathrm{mL})$, respectively (C) only one time point for each control shown), whereas mock-infected cells served as a negative control (green overlay). Changes in $\Delta \psi m$ mere evaluated with DePsipherTM and flow cytometry. With this technique, decreased red fluorescence (FL2) indicates altered $\Delta \psi \mathrm{m}$, an early marker of apoptosis. Data shown is representative of 3 different experiments. Marked changes in $\Delta \psi \mathrm{m}$, indicative of apoptosis, were evident in cells infected with RacL11 at an MOI of 5 after $24 \mathrm{~h}$ and sodium azide controls, but not in cells infected with RacL11 for $4 \mathrm{~h}$ at either MOI or $24 \mathrm{~h}$ after EHV-1 infection with an MOI of 1 or treatment of cells with LPS.

activation of MAP kinases and the transcription factors, $\mathrm{NF \kappa} \beta$, activating protein-1 or early growth response protein-1, all of which were shown to bind to responsive elements in the TF gene promoter and activate transcription $[48,49]$. Further studies, however, are necessary to uncover the signaling pathways by which TF mRNA is upregulated after EHV-1 infection. At higher infectious doses of EHV-1, procoagulant activity was observed in monocytes within $1 \mathrm{~h}$ of infection and was even higher than that seen with LPS. This rapid increase in activity cannot entirely be attributed to de novo TF protein synthesis and it is possible that EHV-1 induces release of intracellular stores of TF or decrypts surface-expressed TF $[50,51]$. The majority of cellular TF is stored intracellularly within endosomes and Golgi vesicles, but studies in human monocytes and fibroblasts have shown that these stores 


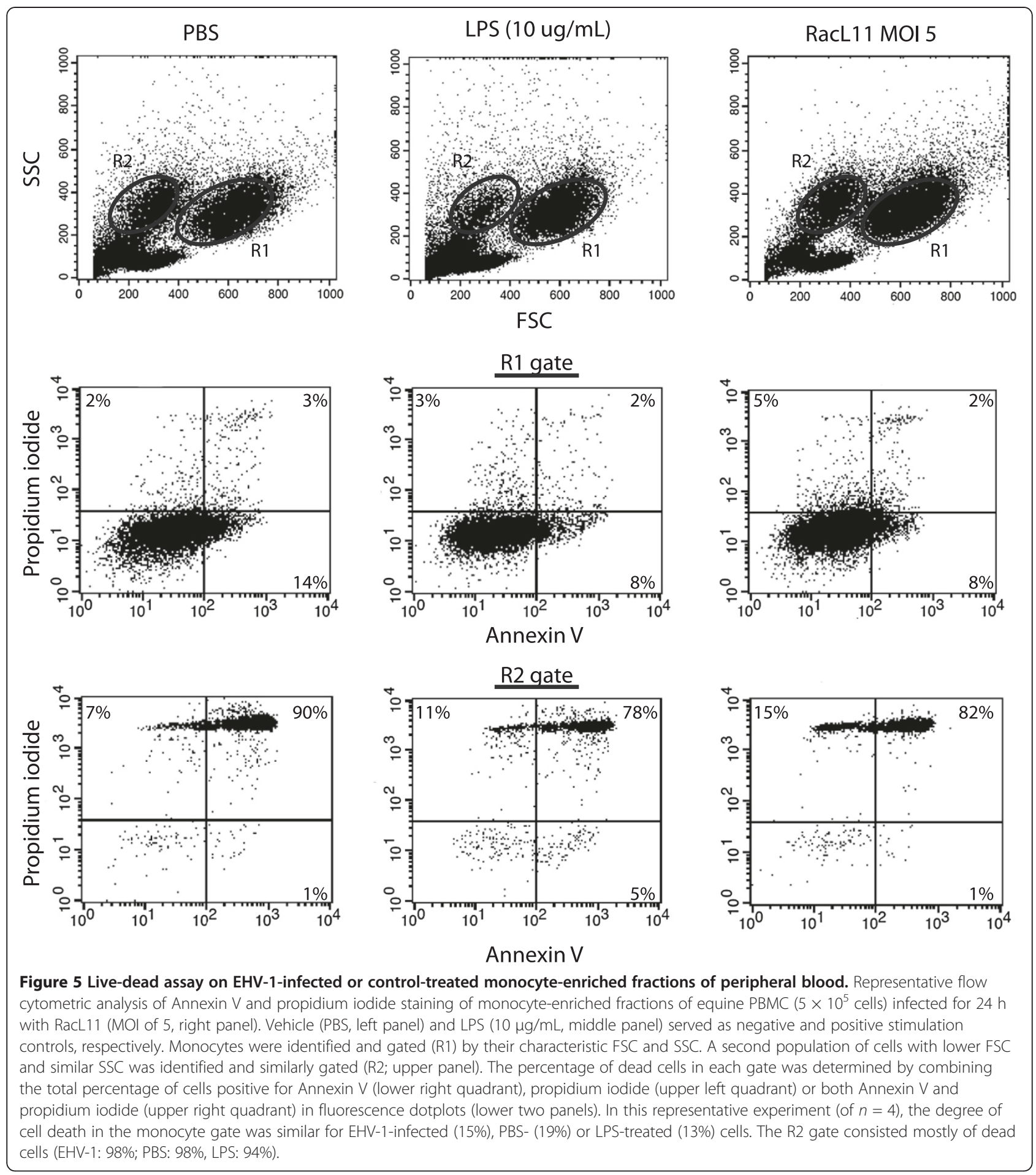

can be mobilized rapidly with appropriate stimulation, including LPS $[41,50]$.

We found that higher infectious doses of EHV-1 resulted in permeable mitochondrial membranes in equine monocytes $24 \mathrm{~h}$ after infection, but this was not concurrently associated with overt cell death. There are several potential explanations for these findings. It is possible that the cell death sequence is initiated at $24 \mathrm{~h}$ and would only fully manifest at a later time. In support of this explanation, we have observed that many monocytes are lysed $48 \mathrm{~h}$ after EHV-1 infection (MOI of 5; data not shown). Mitochondrial membrane changes are potentially reversible [39], but this has not been reported following virus infection. Herpesviruses can upregulate anti- 
Table 5 In vitro culture of monocytes induces cell death, which is not increased by EHV-1 infection

\begin{tabular}{llllll}
\hline Treatment & \multicolumn{2}{c}{ Monocyte gate } & & \multicolumn{2}{c}{ Dead cell gate } \\
\cline { 2 - 3 } & $\%$ total & \% dead & & $\%$ total & $\%$ dead \\
\hline Vehicle & $54 \pm 21$ & $16 \pm 3$ & & $9 \pm 7$ & $65 \pm 29$ \\
LPS & $55 \pm 25$ & $18 \pm 15$ & $6 \pm 4$ & $80 \pm 18$ \\
RacL11 MOI 1 & $59 \pm 17$ & $14 \pm 8$ & $9 \pm 7$ & $79 \pm 24$ \\
RacL11 MOI 5 & $59 \pm 14$ & $16 \pm 10$ & $7 \pm 5$ & $83 \pm 17$ \\
Sodium azide & $33 \pm 26$ & $31 \pm 26$ & & $18 \pm 19$ & $92 \pm 10$ \\
\hline
\end{tabular}

Live-dead assays with Annexin $\mathrm{V}$ and propidium iodide were performed on suspended monocyte-enriched fractions $24 \mathrm{~h}$ after EHV-1 infection with RacL11 (MOI of 1 and 5) or treatment with LPS $(10 \mu \mathrm{g} / \mathrm{mL})$ or vehicle (PBS). Sodium azide $(25 \mathrm{mM})$ was used as a positive control for induction of cell death. The mean \pm SD percentage of total cells and dead cells (expressing Annexin $\mathrm{V}$ or propidium iodide) was calculated in the monocyte and "dead cell" gate (R1 and R2 in Figure 5, respectively) $(n=4)$. Mean percentages for infected or treated cells were not significantly different from vehicle-treated controls $(p>0.05)$.

apoptotic proteins, which could inhibit or delay cell death despite mitochondrial disruption [52]. Since the degree of overt cell death was similar between EHV-1-infected, mock-infected or LPS-stimulated equine monocytes and procoagulant activity was not increased in sodium azide-treated monocytes despite substantial cell death, we could not attribute the increased procoagulant activity at $24 \mathrm{~h}$ after EHV-1 infection to cell death. Our results also indicate that cultured equine monocytes undergo spontaneous cell death, which increases from 4 to $24 \mathrm{~h}$ of culture, but was not enhanced by virus infection or LPS stimulation $(10 \mathrm{ng} / \mathrm{mL}$ or $10 \mu \mathrm{g} / \mathrm{mL})$. Such spontaneous cell death has also been observed in human monocytes cultured in vitro $[53,54]$. Our results with LPS-treated equine monocytes differ from that previously reported with human monocytes, in which a lower dose of LPS $(1 \mu \mathrm{g} / \mathrm{mL})$ induced more cell death than was observed in untreated controls [45]. This could be due to species differences in the response to LPS. The procoagulant response after LPS stimulation was also highest at $24 \mathrm{~h}$ versus $4-6 \mathrm{~h}$ after treatment, as reported previously for horse monocytes [36]. The latter conflicting results may be explained by different experimental methods, since a two-stage amidolytic assay was used to measure procoagulant activity on the surface of living cells in this study whereas a clotting assay was used to measure procoagulant activity in whole cell lysates of equine monocytes in the previous study [36].

The data also revealed strain-dependent differences in generation of procoagulant activity in equine monocytes, with RacL11 consistently eliciting a stronger response than Ab4 or NY03. These strain-dependent differences were not attributable to the $D_{752}$ polymorphism in the DNA polymerase. This polymorphism has been strongly associated with neuropathogenicity $[25,27,32,33]$, possibly due to a leukocyte-associated viremia of higher magnitude and longer duration [25,27] or more efficient infection of CD172-positive mononuclear cells after invasion through the respiratory mucosa $[2,29,44]$. Interestingly, the $D_{752}$ polymorphism in the virus DNA polymerase did affect the maximal procoagulant response induced by RacL11 but not by Ab4. The reason for this is unclear but it is unlikely to be due to virus yields or differences in replication, since previous studies have shown that strains harboring the $\mathrm{D}_{752}$ or $\mathrm{N}_{752}$ polymorphism yield similar amounts of virus $[25,26]$. The result does, however, support our findings with UV-inactivated or aphidicolin-treated virus showing that virus replication contributes to procoagulant activity with EHV-1. The reason for the higher procoagulant activity with RacL11 is unknown, but similar results have been reported for chemokine gene expression patterns, with RacL11 causing higher levels of CCL2 and CCL3 mRNA in equine PBMC than NY03 or Ab4 after $24 \mathrm{~h}$ of infection [55]. Since the observed differences in infection efficiency between RacL11 and Ab4 were small in this study, other factors are likely causative, such as variations in gene products between the virus strains used. The rapid induction of procoagulant activity and TF mRNA transcription suggests that early events in virus infection, such as attachment, entry, intracellular trafficking or transcription of immediate-early genes [56], may be mediating the observed procoagulant responses. RacL11 differs from the other two strains by partial or complete deletions in open reading frames 1 and 2, that encode early gene products, and also has a large deletion in the early gene product, ICPO, a powerful transcriptional transactivator [57]. To the authors' knowledge, there are no EHV-1 strain differences in the gC envelope glycoprotein, which facilitates herpes simplex virus-induced procoagulant responses in human umbilical vein endothelial cells [58]. Future studies are required to elucidate which virus gene(s) are responsible for strain-dependent differences in procoagulant activity in equine monocytes.

Procoagulant activity was induced after addition of EHV-1 or EHV-4 to monocyte-enriched fractions. The effect was partly replication-dependent in the case of EHV-1, but not with EHV-4, as shown by inhibition with UV light inactivation of the virus and aphidicolin treatment of infected cells. EHV-4 does not appear to efficiently replicate in monocytes $[43,44]$, which may explain the lack of replication-dependent procoagulant activity with this virus. However, since procoagulant activity independent of virus replication was seen with both viruses, early events such as virus attachment, entry or intracellular trafficking, appear sufficient to induce this response and may even be required for the maximal procoagulant activity that is induced by replication with EHV-1. Similar results have been reported with endothelial cell infection by herpes simplex virus and avian hemangioma retrovirus $[59,60]$. It is possible that the procoagulant response in monocytes is 
part of an innate immune response of host cells to virus infection. There is a mounting body of evidence that coagulation factors, including TF, can stimulate inflammatory and immune responses, through cleavage of protease-activated receptors (PARs) [61,62]. Interactions of EHV-1 glycoproteins with cell surface receptors or recognition of CpG-rich virus DNA by intracellular Toll-like receptors or cytosolic DNA-dependent RNA polymerase following virus binding and uptake may activate signaling pathways resulting in TF gene transcription and other immune responses, such as chemokine secretion $[63,64]$. The virus could also co-opt both innate immune receptors and the hemostatic system to support its own replication. For instance, both TF and thrombin, through activation of PAR2 and PAR1 respectively, increase the susceptibility of human umbilical vein endothelial cells to herpes simplex virus infection $[65,66]$.

There is some controversy over which mononuclear cell in peripheral blood is responsible for the PBMCassociated viremia seen after EHV-1 infection. The cytotoxic $\mathrm{T}$ lymphocyte has been implicated as the main cell responsible for both EHV-1 latency and viremia after in vivo infection [5,67]. However, this study and others have shown that the virus is predominantly found in monocytes and B lymphocytes after in vitro infection of PBMC $[25,26]$. Furthermore, in vivo and in vitro studies with equine nasal explants suggest that the main targets of infection after uptake and replication within the nasal mucosa are CD172-positive mononuclear cells, which are either monocytes, dendritic cells or neutrophils [2,29,44]. It is possible that monocytes are the vehicle of virus transfer to endothelial cells in the placenta and central nervous system $[3,6,7]$. In support of this, EHV-1 virus gene products have been amplified from monocyte-enriched fractions of peripheral blood after in vivo infection [5].

Since TF triggers the initiation phase of coagulation in vivo, its induced expression on monocytes could contribute to the pathologic thrombosis associated with EHV-1 infection. However, systemic vascular thrombosis is not a typical finding in EHV-1-infected horses; rather, thrombosis has been observed in specific vascular beds, including arterioles of the nasal mucosa (after aerosol challenge), arterioles, venules and capillaries in the spinal cord and brain, and arterioles in the placenta [8-10]. These observations indicate that monocyte-associated TF is unlikely to be the sole cause of thrombosis in EHV-1-infected horses and other factors are involved. These factors could include, but are not limited to, upregulation of vascular bed-specific adhesion molecules, which mediate adhesion of TF-bearing monocytes to regional endothelial cells [6,7], high regional expression of procoagulant factors in infected monocytes and endothelial cells [16,17], and downregulated local anticoagulant defenses [16].
Collectively, our results show that various strains of EHV-1 induce procoagulant activity in equine monocytes as early as $1 \mathrm{~h}$ after infection. The procoagulant activity could contribute to the thrombosis observed in EHV-1associated disease syndromes in horses, but could also be a mechanism by which the virus co-opts host responses to facilitate replication and dissemination in the animal. Since procoagulant activity does not require virus replication and also occurs with other herpesviruses that are not associated with thrombosis in vivo, it is also possible that the induced procoagulant activity in this inflammatory cell may be a natural component of the host defense against the virus. Elucidating the virus proteins and specific signaling pathways through which EHV-1 induces procoagulant responses in monocytes could provide valuable insight into general mechanisms of how viruses affect the innate immune response and co-opt the hemostatic system of an infected host.

\section{Abbreviations}

$\Delta \Psi \mathrm{m}$ : Mitochondrial transmembrane potential; cDNA: Complementary DNA; EHV-1: Equine herpesvirus type 1; EHV-4: Equine herpesvirus type 4; FVIlla: Activated factor VII; FSC: Forward scatter; FX: Factor X; FXa: Activated factor X; GFP: Green fluorescent protein; LPS: Lipopolysaccharide; MOI: Multiplicity of infection; PAR: Protease-activated receptor; PBMC: Peripheral blood mononuclear cells; PBS: Phosphate-buffered saline; SSC: Side scatter; TF: Tissue factor; UV: Ultraviolet.

\section{Competing interests}

The authors declare that they have no competing interests.

\section{Authors' contributions}

WMY performed all experiments in the study, including virus and monocyte purification, monocyte infection, procoagulant activity assays, mRNA isolation, flow cytometric analysis, real time PCR and statistical analysis, and drafted the manuscript. KO participated in the design of the study, provided reagents and helped draft the manuscript. TS conceived of the study, participated in its design and co-ordination, helped with statistical analysis, performed the differential cell counts on cytospin smears of monocyteenriched fractions, analyzed live-dead data, generated the figures, and helped draft the manuscript. All authors have read and approved of the manuscript.

\section{Authors' information}

Dr Yeo is a post-doctoral associate in Dr Stokol's laboratory. Dr Osterrieder is the current director of the Institut für Virologie, Freie Universität Berlin. Dr Stokol is a board-certified clinical pathologist and Associate Professor at Cornell University.

\section{Acknowledgements}

This study was funded by a Morris Animal Foundation grant, \#D09EQ-009. The authors would like to thank Emily Silvela at the McConville Barn, Scott Baxendell and Alexa Fland at the Equine Research Park, Dr D. Antczak, Dr B. Wagner and Dr E. Dubovi for help with obtaining blood samples from the horses and provision of reagents or supplies.

\section{Author details}

'Department of Population Medicine and Diagnostic Sciences, College of Veterinary Medicine, Cornell University, Ithaca, NY, USA. ${ }^{2}$ Institut für Virologie, Freie Universität Berlin, Philippstraße 13, Berlin, 10115, Germany.

Received: 24 July 2012 Accepted: 18 February 2013

Published: 11 March 2013 


\section{References}

1. Lunn DP, Davis-Poynter N, Flaminio MJ, Horohov DW, Osterrieder K, Pusterla $\mathrm{N}$, Townsend HG: Equine herpesvirus-1 consensus statement. J Vet Intern Med 2009, 23:450-461.

2. Gryspeerdt AC, Vandekerckhove AP, Garre B, Barbe F, Van de Walle GR, Nauwynck HJ: Differences in replication kinetics and cell tropism between neurovirulent and non-neurovirulent EHV1 strains during the acute phase of infection in horses. Vet Microbiol 2010, 142:242-253.

3. Goehring LS, Hussey GS, Ashton LV, Schenkel AR, Lunn DP: Infection of central nervous system endothelial cells by cell-associated EHV-1. Vet Microbiol 2011, 148:389-395.

4. Goehring LS, van Maanen C, Berendsen M, Cullinane A, de Groot RJ, Rottier PJ, Wesselingh JJ, van Oldruitenborgh-Oosterbaan MM S: Experimental infection with neuropathogenic equid herpesvirus type 1 (EHV-1) in adult horses. Vet J 2010, 186:180-187.

5. Wilsterman S, Soboll-Hussey G, Lunn DP, Ashton LV, Callan RJ, Hussey SB, Rao S, Goehring LS: Equine herpesvirus-1 infected peripheral blood mononuclear cell subpopulations during viremia. Vet Microbiol 2011 149:40-47.

6. Smith $D$, Hamblin A, Edington N: Equid herpesvirus 1 infection of endothelial cells requires activation of putative adhesion molecules: an in vitro model. Clin Exp Immunol 2002, 129:281-287.

7. Smith DJ, Hamblin AS, Edington N: Infection of endothelial cells with equine herpesvirus-1 (EHV-1) occurs where there is activation of putative adhesion molecules: a mechanism for transfer of virus. Equine Vet J 2001, 33:138-142.

8. Smith KC, Mumford JA, Lakhani K: A comparison of equid herpesvirus-1 (EHV-1) vascular lesions in the early versus late pregnant equine uterus. J Comp Pathol 1996, 114:231-247.

9. Edington N, Bridges CG, Patel JR: Endothelial cell infection and thrombosis in paralysis caused by equid herpesvirus-1: equine stroke. Arch Virol 1986, 90:111-124.

10. Edington N, Smyth B, Griffiths $L$ : The role of endothelial cell infection in the endometrium, placenta and foetus of equid herpesvirus 1 (EHV-1) abortions. J Comp Pathol 1991, 104:379-387.

11. Levi M, Schultz M, van der Poll T: Disseminated intravascular coagulation in infectious disease. Semin Thromb Hemost 2010, 36:367-377.

12. Bunce PE, High SM, Nadjafi M, Stanley K, Liles WC, Christian MD: Pandemic H1N1 influenza infection and vascular thrombosis. Clin Infect Dis 2011, 52:e14-17.

13. McSorley J, Shapiro L, Brownstein MH, Hsu KC: Herpes simplex and varicella-zoster: comparative histopathology of 77 cases. Int J Dermatol 1974, 13:69-75.

14. Pawlinski R, Mackman N: Cellular sources of tissue factor in endotoxemia and sepsis. Thromb Res 2010, 125(Suppl 1):S70-73.

15. Moons AH, Peters RJ, Cate H, Bauer KA, Vlasuk GP, Buller HR, Levi M: Recombinant nematode anticoagulant protein $\mathrm{C2}$, a novel inhibitor of tissue factor-factor Vlla activity, abrogates endotoxin-induced coagulation in chimpanzees. Thromb Haemost 2002, 88:627-631.

16. Key NS, Vercellotti GM, Winkelmann JC, Moldow CF, Goodman JL, Esmon $\mathrm{NL}$, Esmon CT, Jacob HS: Infection of vascular endothelial cells with herpes simplex virus enhances tissue factor activity and reduces thrombomodulin expression. Proc Natl Acad Sci U S A 1990, 87:7095-7099.

17. Vercellotti GM: Proinflammatory and procoagulant effects of herpes simplex infection on human endothelium. Blood Cells 1990, 16:209-215. discussion 215-206.

18. Visseren FL, Bouwman JJ, Bouter KP, Diepersloot RJ, de Groot PH, Erkelens DW: Procoagulant activity of endothelial cells after infection with respiratory viruses. Thromb Haemost 2000, 84:319-324.

19. Osterud B: Tissue factor expression in blood cells. Thromb Res 2010, 125(Suppl 1):S31-34.

20. Olchowy TW, Slauson DO, Bochsler PN: Induction of procoagulant activity in virus infected bovine alveolar macrophages and the effect of lipopolysaccharide. Vet Immunol Immunopathol 1997, 58:27-37.

21. Bouwman JJ, Visseren FL, Bosch MC, Bouter KP, Diepersloot RJ: Procoagulant and inflammatory response of virus-infected monocytes. Eur J Clin Invest 2002, 32:759-766.

22. Geisbert TW, Young HA, Jahrling PB, Davis K, Kagan E, Hensley LE: Mechanisms underlying coagulation abnormalities in ebola hemorrhagic fever: overexpression of tissue factor in primate monocytes/ macrophages is a key event. J Infect Dis 2003, 188:1618-1629.
23. Funderburg NT, Mayne E, Sieg SF, Asaad R, Jiang W, Kalinowska M, Luciano AA, Stevens W, Rodriguez B, Brenchley JM, Douek DC, Lederman MM: Increased tissue factor expression on circulating monocytes in chronic HIV infection: relationship to in vivo coagulation and immune activation. Blood 2010, 115:161-167.

24. Muramoto Y, Ozaki H, Takada A, Park CH, Sunden Y, Umemura T, Kawaoka Y, Matsuda H, Kida H: Highly pathogenic H5N1 influenza virus causes coagulopathy in chickens. Microbiol Immunol 2006, 50:73-81.

25. Goodman LB, Loregian A, Perkins GA, Nugent J, Buckles EL, Mercorelli B, Kydd JH, Palu G, Smith KC, Osterrieder N, Davis-Poynter N: A point mutation in a herpesvirus polymerase determines neuropathogenicity. PLoS Pathog 2007, 3:e160.

26. $\mathrm{Ma} \mathrm{G}$, Lu C, Osterrieder N: Residue 752 in DNA polymerase of equine herpesvirus type 1 is non-essential for virus growth in vitro. $J$ Gen Virol 2010, 91:1817-1822.

27. Van de Walle GR, Goupil R, Wishon C, Damiani A, Perkins GA, Osterrieder N: A single-nucleotide polymorphism in a herpesvirus DNA polymerase is sufficient to cause lethal neurological disease. J Infect Dis 2009, 200:20-25.

28. Kydd JH, Smith KC, Hannant D, Livesay GJ, Mumford JA: Distribution of equid herpesvirus-1 (EHV-1) in respiratory tract associated lymphoid tissue: implications for cellular immunity. Equine Vet J 1994, 26:470-473.

29. Vandekerckhove AP, Glorieux S, Gryspeerdt AC, Steukers L, Duchateau L, Osterrieder N, Van de Walle GR, Nauwynck HJ: Replication kinetics of neurovirulent versus non-neurovirulent equine herpesvirus type 1 strains in equine nasal mucosal explants. J Gen Virol 2010, 91:2019-2028.

30. Reczko E, Mayr A: On the fine structure of a virus of the herpes group isolated from horses. Arch Gesamte Virusforsch, 1963, 13:591-593 (in German).

31. Van de Walle GR, May MA, Peters ST, Metzger SM, Rosas CT, Osterrieder N: A vectored equine herpesvirus type 1 (EHV-1) vaccine elicits protective immune responses against EHV-1 and H3N8 equine influenza virus. Vaccine 2010, 28:1048-1055.

32. Nugent J, Birch-Machin I, Smith KC, Mumford JA, Swann Z, Newton JR, Bowden RJ, Allen GP, Davis-Poynter N: Analysis of equid herpesvirus 1 strain variation reveals a point mutation of the DNA polymerase strongly associated with neuropathogenic versus nonneuropathogenic disease outbreaks. J Virol 2006, 80:4047-4060.

33. Perkins GA, Goodman LB, Tsujimura K, Van de Walle GR, Kim SG, Dubovi EJ, Osterrieder N: Investigation of the prevalence of neurologic equine herpes virus type 1 (EHV-1) in a 23-year retrospective analysis (1984-2007). Vet Microbiol 2009, 139:375-378.

34. Neubauer A, Rudolph J, Brandmuller C, Just FT, Osterrieder N: The equine herpesvirus 1 UL34 gene product is involved in an early step in virus egress and can be efficiently replaced by a UL34-GFP fusion protein. Virology 2002, 300:189-204

35. Kabithe E, Hillegas J, Stokol T, Moore J, Wagner B: Monoclonal antibodies to equine CD14. Vet Immunol Immunopathol 2010, 138:149-153.

36. Henry MM, Moore JN: Endotoxin-induced procoagulant activity in equine peripheral blood monocytes. Circ Shock 1988, 26:297-309.

37. Schmittgen TD, Livak KJ: Analyzing real-time PCR data by the comparative C(T) method. Nat Protoc 2008, 3:1101-1108.

38. Zamzami N, Marchetti P, Castedo M, Zanin C, Vayssiere JL, Petit PX, Kroemer G: Reduction in mitochondrial potential constitutes an early irreversible step of programmed lymphocyte death in vivo. J Exp Med 1995, 181:1661-1672.

39. Chen Q, Takeyama N, Brady G, Watson AJ, Dive C: Blood cells with reduced mitochondrial membrane potential and cytosolic cytochrome $\mathrm{C}$ can survive and maintain clonogenicity given appropriate signals to suppress apoptosis. Blood 1998, 92:4545-4553.

40. Sutherland MR, Raynor CM, Leenknegt H, Wright JF, Pryzdial EL: Coagulation initiated on herpesviruses. Proc Natl Acad Sci U S A 1997, 94:13510-13514.

41. Egorina EM, Sovershaev MA, Bjorkoy G, Gruber FX, Olsen JO, Parhami-Seren B, Mann KG, Osterud B: Intracellular and surface distribution of monocyte tissue factor: application to intersubject variability. Arterioscler Thromb Vasc Biol 2005, 25:1493-1498.

42. Dicioccio RA, Chadha K, Sahai Srivastava BI: Inhibition of herpes simplex virus-induced DNA polymerase, cellular DNA polymerase alpha, and virus production by aphidicolin. Biochim Biophys Acta 1980, 609:224-231.

43. Van de Walle GR, Peters ST, VanderVen BC, O'Callaghan DJ, Osterrieder N: Equine herpesvirus 1 entry via endocytosis is facilitated by alphaV integrins and an RSD motif in glycoprotein D. J Virol 2008, 82:11859-11868. 
44. Vandekerckhove AP, Glorieux S, Gryspeerdt AC, Steukers L, Van Doorsselaere J, Osterrieder N, Van de Walle GR, Nauwynck HJ: Equine alphaherpesviruses (EHV-1 and EHV-4) differ in their efficiency to infect mononuclear cells during early steps of infection in nasal mucosal explants. Vet Microbiol 2011, 152:21-28.

45. Henriksson CE, Klingenberg O, Ovstebo R, Joo GB, Westvik AB, Kierulf P: Discrepancy between tissue factor activity and tissue factor expression in endotoxin-induced monocytes is associated with apoptosis and necrosis. Thromb Haemost 2005, 94:1236-1244.

46. Henriksson CE, Hellum M, Landsverk KS, Klingenberg O, Joo GB, Kierulf P: Flow cytometry-sorted non-viable endotoxin-treated human monocytes are strongly procoagulant. Thromb Haemost 2006, 96:29-37.

47. Gregory SA, Morrissey JH, Edgington TS: Regulation of tissue factor gene expression in the monocyte procoagulant response to endotoxin. $\mathrm{Mol}$ Cell Biol 1989, 9:2752-2755.

48. Guha M, O'Connell MA, Pawlinski R, Hollis A, McGovern P, Yan SF, Stern D, Mackman N: Lipopolysaccharide activation of the MEK-ERK1/2 pathway in human monocytic cells mediates tissue factor and tumor necrosis factor alpha expression by inducing Elk-1 phosphorylation and Egr-1 expression. Blood 2001, 98:1429-1439.

49. Mackman N, Brand K, Edgington TS: Lipopolysaccharide-mediated transcriptional activation of the human tissue factor gene in THP-1 monocytic cells requires both activator protein 1 and nuclear factor kappa B binding sites. J Exp Med 1991, 174:1517-1526.

50. Mandal SK, Pendurthi UR, Rao LV: Cellular localization and trafficking of tissue factor. Blood 2006, 107:4746-4753.

51. Bach RR: Tissue factor encryption. Arterioscler Thromb Vasc Biol 2006, 26:456-461.

52. Jerome KR, Chen Z, Lang R, Torres MR, Hofmeister J, Smith S, Fox R, Froelich CJ, Corey L: HSV and glycoprotein J inhibit caspase activation and apoptosis induced by granzyme B or Fas. J Immunol 2001, 167:3928-3935.

53. Poitevin S, Ben Hadj Kalifa Kechiche S, Mace C, Nguyen P: IL-10 inhibits apoptosis and microvesiculation of human monocytes. J Thromb Haemost 2009, 7:1241-1243.

54. Lund PK, Namork E, Brorson SH, Westvik AB, Joo GB, Ovstebo R, Kierulf P: The fate of monocytes during $24 \mathrm{~h}$ of culture as revealed by flow cytometry and electron microscopy. J Immunol Methods 2002, 270:63-76.

55. Wimer CL, Damiani A, Osterrieder N, Wagner B: Equine herpesvirus type-1 modulates CCL2, CCL3, CCL5, CXCL9, and CXCL10 chemokine expression. Vet Immunol Immunopathol 2011, 140:266-274.

56. Gray WL, Baumann RP, Robertson AT, Caughman GB, O'Callaghan DJ, Staczek J: Regulation of equine herpesvirus type 1 gene expression: characterization of immediate early, early, and late transcription. Virology 1987, 158:79-87.

57. Kim SK, Jang HK, Albrecht RA, Derbigny WA, Zhang Y, O'Callaghan DJ: Interaction of the equine herpesvirus 1 EICP0 protein with the immediateearly (IE) protein, TFIIB, and TBP may mediate the antagonism between the IE and EICPO proteins. J Virol 2003, 77:2675-2685.

58. Sutherland MR, Friedman HM, Pryzdial EL: Herpes simplex virus type 1encoded glycoprotein C enhances coagulation factor Vlla activity on the virus. Thromb Haemost 2004, 92:947-955.

59. Key NS, Bach RR, Vercellotti GM, Moldow CF: Herpes simplex virus type I does not require productive infection to induce tissue factor in human umbilical vein endothelial cells. Lab Invest 1993, 68:645-651.

60. Resnick-Roguel N, Eldor A, Burstein H, Hy-Am E, Vlodavsky I, Panet A Blajchman MA, Kotler M: Envelope glycoprotein of avian hemangioma retrovirus induces a thrombogenic surface on human and bovine endothelial cells. J Virol 1990, 64:4029-4032.

61. Busso N, Chobaz-Peclat V, Hamilton J, Spee P, Wagtmann N, So A: Essential role of platelet activation via protease activated receptor 4 in tissue factor-initiated inflammation. Arthritis Res Ther 2008, 10:R42.

62. Pawlinski R, Mackman N: Tissue factor, coagulation proteases, and protease-activated receptors in endotoxemia and sepsis. Crit Care Med 2004, 32:S293-297.

63. Takeda S, Miyazaki D, Sasaki S, Yamamoto Y, Terasaka Y, Yakura K, Yamagami $S$, Ebihara N, Inoue $Y$ : Roles played by toll-like receptor-9 in corneal endothelial cells after herpes simplex virus type 1 infection. Invest Ophthalmol Vis Sci 2011, 52:6729-6736.

64. Kim JS, Park DW, Lee HK, Kim JR, Baek SH: Early growth response-1 is involved in foam cell formation and is upregulated by the TLR9-MyD88 -ERK1/2 pathway. Biochem Biophys Res Commun 2009, 390:196-200.
65. Sutherland MR, Friedman HM, Pryzdial EL: Thrombin enhances herpes simplex virus infection of cells involving protease-activated receptor 1. J Thromb Haemost 2007, 5:1055-1061.

66. Sutherland MR, Ruf W, Pryzdial EL: Tissue factor and glycoprotein C on herpes simplex virus type 1 are protease-activated receptor 2 cofactors that enhance infection. Blood 2012, 119:3638-3645.

67. Smith DJ, lqbal J, Purewal A, Hamblin AS, Edington N: In vitro reactivation of latent equid herpesvirus-1 from CD5+/CD8+ leukocytes indirectly by IL-2 or chorionic gonadotrophin. J Gen Virol 1998, 79:2997-3004.

doi:10.1186/1297-9716-44-16

Cite this article as: Yeo et al:: Equine herpesvirus type 1 infection induces procoagulant activity in equine monocytes. Veterinary Research 2013 44:16

\section{Submit your next manuscript to BioMed Central and take full advantage of:}

- Convenient online submission

- Thorough peer review

- No space constraints or color figure charges

- Immediate publication on acceptance

- Inclusion in PubMed, CAS, Scopus and Google Scholar

- Research which is freely available for redistribution 